\title{
Phosphorus pools in soil after land conversion from silvopasture to arable and grassland use
}

\author{
Anna Slazak ${ }^{*}$, Dirk Freese1, Eduardo S. Matos², Seth Nii-Annang1, and Reinhard F. Hüttt11,3 \\ 1 Chair of Soil Protection and Recultivation, Brandenburg University of Technology, P.O. Box 1013 44, 03013 Cottbus, Germany \\ 2 Embrapa Agrosilvopastoral, P.O. Box 343, 78550-970, Sinop-MT, Brazil \\ 3 Helmholtz-Centre Potsdam - GFZ, German Research Centre for Geosciences, Telegrafenberg, 14473 Potsdam, Germany
}

\begin{abstract}
Differences in soil $\mathrm{P}$ among silvopasture, grassland, and arable lands have been well established. Nevertheless, most of the reports compare soil properties under long-term sites. Thus, there exists little information on the effect of the conversion of silvopasture to arable or grassland use on soil P pools. The objective of the study was to determine the impact of converting silvopasture system (SP) into arable cropping and grassland system on the distribution of $\mathrm{P}$ pools and potential P bioavailability. We compared the following systems: SP system, SP converted to arable cropland (SP-AL), SP converted to grassland (SP-GL), and for comparative purposes, a long-term arable cropland (AL). The $P$ fractionation was performed by a sequential extraction scheme, using acid and alkaline extractants on samples collected from the $0-10$ and $10-20 \mathrm{~cm}$ soil layers. It was assumed that the large variations in soil- $P$ fractionations are caused by the different management practices associated with land conversion. The results of $P$ fractionation showed a dominance of calcium-bound $\mathrm{P}, \mathrm{HCl}$-extractable $\mathrm{Pi}$ constituted up to $36 \%$ of the soil total P (TP). However, the type of land use did not affect this $P$ fraction. On the other hand, the reduction in labile- $\mathrm{P}_{\mathrm{i}}$ and $\mathrm{NaOH}-\mathrm{P}_{\mathrm{i}}$ fractions observed at the SP-AL site may have led to the decline in readily available $\mathrm{P}$. The soil total organic $\mathrm{P}\left(\mathrm{TP}_{\mathrm{o}}\right)$ content was $8 \%$ and $17 \%$ lower at SP-AL compared to SP and SP-GL site, respectively. Labile organic-P (labile- $\mathrm{P}_{\mathrm{o}}$ ) content was markedly higher at SP site compared to arable soils, and was $\approx 10 \%$ of $\mathrm{TP}_{\mathrm{o}}$. The $\mathrm{NaOH}-\mathrm{P}_{\mathrm{o}}$ constituted the highest fraction of the organic-P pool $\left(55 \%-79 \%\right.$ of $\left.\mathrm{TP}_{\mathrm{o}}\right)$ across all the study systems, and was positively correlated with $\operatorname{TP}_{\mathrm{O}}(p<0.01)$. The study indicates that conversion of $\mathrm{SP}$ system in temperate regions to arable cropping with conventional tillage seems to result in the reduction of $\mathrm{P}$ availability compared to $\mathrm{SP}$, indicating $\mathrm{SP}$ as an important land-use practice.
\end{abstract}

Key words: sequential P fractionation / P availability / agricultural soils / silvopastoral / land-use

Accepted April 18, 2013

\section{Introduction}

It is well known that agricultural practices and different soil management affects the distribution of soil P. Even though it is important to study the impact of changes in land-use practices on the distribution of soil $P$, detailed knowledge on soil $P$ fractions is necessary. The $\mathrm{P}$-fractionation procedure determines the various form of soil organic and inorganic $P$ based on their solubility in different chemical reagents (Cross and Schlesinger, 1995; Bowman and Cole, 1978a). An aspect of different land-use practices on soil $P$ characteristic has been discussed in several studies (Brookes et al., 1984; Condron et al., 2005; Cross and Schlesinger, 1995; Di et al., 1996; Khan and Joergensen, 2012; Martens et al., 2004; Michel et al., 2007; Sanyal and De Datta, 1991; Staley et al., 2008). Nevertheless, most of the studies that focused on inorganic and organic $\mathrm{P}$ in different ecosystems, examined the shortand long-term effects of land-use (Alt et al., 2011; Bowman and Cole, 1978a; Lilienfein et al., 2000; McKenzie et al., 1992; Sharpley and Smith, 1985; Song et al., 2007; Tiessen et al., 1983). These studies showed that cultivation without $P$ fertilizer led to depletion of most of the $\mathrm{P}$ fraction (mainly labile P pools); higher in continuous monocultures than in the crop rotations. McKenzie et al. (1992) reported less reduction in different $\mathrm{P}$ pools in crop rotations compared to continuous wheat monoculture. Nevertheless, studies on silvopastoral systems (SP) by Michel et al. (2007) and Nair et al. (2007) proved that the capacity of soil to store $\mathrm{P}$ is lower in treeless pasture compared to SP systems. These studies also showed that the presence of trees in pasture may reduce the likelihood of future additions of $P$ being removed from the soil. For example, work of Magid (1993) in Denmark, Guggenberger et al. (1996) in Germany, and Ellert and Gregorich (1996) in Australia revealed higher total organic $\mathrm{P}\left(\mathrm{TP}_{\mathrm{o}}\right)$ contents under pasture than under forest. Besides, Alt et al. (2011) in Germany and Turrion et al. (2001) in Spain reported higher $\mathrm{TP}_{\mathrm{o}}$ and $\mathrm{P}$ availability under grassland and pasture compared to forest. Also, depletion of $\mathrm{TP}_{\mathrm{o}}$ caused by land cultivation has been reported by several authors (Chen et al., 2000; Staley et al., 2008; Tiessen et al., 1982, 1983). However, most of these studies concentrated on pastures, grassland, and arable lands, and the conversion of pasture or silvo-

\footnotetext{
* Correspondence: A. Slazak; e-mail: am.slazak@gmail.com
} 
pasture to forest (Ellert and Gregorich, 1996; Guggenberger et al., 1996; Magid, 1993; Staley et al., 2008).

To the best of our knowledge there are limited researches on the effect of converting silvopastoral system to grassland and/or arable cropping, and more particularly, its influence on $\mathrm{P}$ distribution in soils in Germany. The studies that has been conducted by Matos et al. (2011), related only to the soil organic- $C$ fractions. Therefore, the overall aim of this study was to obtain information on the changes in soil properties, especially in soil organic- $P$ fractions, in order to better understand the $\mathrm{P}$ availability wrought by conversion of long-term silvopasture to arable land and grassland. In addition, the inorganic $\mathrm{P}$ pools have been presented and discussed.

\section{Materials and methods}

\subsection{Study-site description}

The study sites are located in NE Germany, in the Gransee area $\left(53^{\circ} 00^{\prime} \mathrm{N}, 13^{\circ} 08^{\prime} \mathrm{E}\right)$ with a mean annual rainfall of $568 \mathrm{~mm}$ and annual temperature of $9.7^{\circ} \mathrm{C}$. The soil type across the study sites is a Luvic Arenosol according to FAO classification with loamy-sand texture. The investigated area comprised four different land-use systems: (1) silvopasture (SP); (2) continuous-use arable land (AL); (3) silvopasture converted to grassland (SP-GL); (4) silvopasture converted to arable land (SP-AL). The sites were used and managed by farmers prior to our study. Thus, information on the amount of fertilizer applied to the field was obtained from the farmers.

The SP system has been continuously managed for $>50 \mathrm{y}$. The vegetation cover of SP system consists of a mixture of hardwood (apples tress-Malus domestica L. planted in rows of $8 \mathrm{~m} \times 8 \mathrm{~m}$ ) and grass (orchard grass-Dactylis glomerata L.). The site was cultivated as a fruit garden between 1960 and 1989. Additionally, cattle grazing wasa used on temporal basis at a low to moderate grazing intensity, during this period (50 cattle $\left.60 \mathrm{~d}^{-1} \mathrm{y}^{-1}\right)$. The area covers $\approx 3$ ha.

The AL site has been continuously used as arable land for $>50 \mathrm{y}$, with different crop-rotation systems. Recent rotations consist of barley (Hordeum vulgare L.), sunflower (Helianthus annuus L.), and rye (Secale cereale L.) with $\mathrm{N}$ fertilizer of 100,50 , and $100 \mathrm{~kg} \mathrm{ha}^{-1}$, respectively, applied annually per cultivation; no P-fertilizer application (personal communication with the farmer). The management system comprises conventional practice by disc plowing the soil up to $20 \mathrm{~cm}$ depth each second year, and disc harrowing twice per year. The study site is 8 ha in size.

The SP-GL system was converted to grassland in 2004 after $>46$ y of silvopastural use. Neither fertilizer nor manure was applied to the land after conversion. The size of the SP-GL site is 3 ha; located close to SP and AL sites, and covered mainly by orchard grass (Dactylis glomerata L.).

The SP-AL system was converted from SP system to arable use in 2004. After conversion, $4.0 \mathrm{Mg} \mathrm{ha}^{-1}$ of lime was applied in the same year. The crop-rotation system followed was lupine (Lupinus polyphyllus L.), oat (Avena sativa L.), and rape (Brassica napus L.) with annual fertilizer application of 100,200 , and $130 \mathrm{~kg} \mathrm{~N} \mathrm{ha}^{-1}$, respectively, and no P-fertilizer application (personal communication with the farmer). The SP-AL site is $\approx 8$ ha, and was cultivated using conventional tillage system by disc plowing the soil up to $20 \mathrm{~cm}$ depth each second year and twice disc harrowing.

Samples were collected from each study site at the same time, during the first phase of vegetative growth (April 2008). For each study site, soil samples were taken from three independent plots at two depths: $0-10 \mathrm{~cm}$ and $10-20 \mathrm{~cm}$. Soil sample collected from each plot was a composite of 40 subsamples bulked together. Fresh subsamples were stored at $4^{\circ} \mathrm{C}$ in plastic bags until the final analysis carried out. The remaining soil sample was air-dried, passed through 2-mm sieve, finely ground, and stored for subsequent chemical analyses. More details on the sites and sampling procedure are given in Matos et al. (2011).

\subsection{Chemical analyses}

Soil samples were analyzed for total organic $C$ (TOC) and total N (TN) by dry combustion (Vario El Elementar Analyzer). The $\mathrm{pH}$ was determined in deionized water $(1: 2.5)$ using glass electrode. The soil total P (TP) was determined by inductively coupled plasma-emission spectrometry (ICP) after digestion with $\mathrm{HNO}_{3}$. In Germany, this type of extractant is acknowledged for the characterization of TP. The $\mathrm{P}_{\mathrm{MB}}$ was determined by the irradiation-extraction method (Islam and Weil, 1998) using $0.5 \mathrm{M} \mathrm{NaHCO}_{3}(\mathrm{pH} 8.5)$ as extractant (Brookes et al., 1982). The $\mathrm{P}$ concentration was quantified by the ammonium-molybdate-ascorbic method (Murphy and Riley, 1962) using spectrophotometer (Uvikon) with the absorbance at $880 \mathrm{~nm}$. The content of $P_{M B}$ was calculated as the difference between $\mathrm{P}$ concentration in irradiated and nonirradiated samples (based on dry mass) divided by a conversion factor of 0.40 (Brookes et al., 1982). Oxalate Al and Fe $\left(\mathrm{Al}_{\mathrm{ox}}\right.$ and $\mathrm{Fe}_{\mathrm{ox}}$ ) were determined according to Schwertmann (1964) and McKeague and Day (1966) by the acid-ammonium oxalate extraction $(\mathrm{pH}=3)$ in the dark.

\subsection{Soil organic-P fractionation}

Soil organic $P\left(P_{0}\right)$ was fractionated by following four-step sequential extraction procedure of Bowman and Cole (1978a), further modified by Sharpley and Smith (1985). An amount of $5 \mathrm{~g}$ of air-dried soil was sequentially fractionated into different soil $P_{\circ}$ pools: (1) labile $P$-pool fraction, which is weakly adsorbed on mineral surface was extracted by $0.5 \mathrm{M}$ $\mathrm{NaHCO}_{3}\left(\mathrm{pH}=8.5\right.$ ) (labile- $\mathrm{P}_{\mathrm{o}}$ ); (2) moderately labile $\mathrm{P}$ pool, which represents dissolved acid-soluble fraction in the form of calcium phosphates was obtained by extraction with $1.0 \mathrm{M}$ $\mathrm{HCl}\left(\mathrm{HCl}-\mathrm{P}_{\mathrm{o}}\right)$; and (3) more resistant $\mathrm{P}_{\mathrm{o}}$ pool, which is associated with humic compounds and more strongly held by chemisorption to $\mathrm{Fe}$ and $\mathrm{Al}$ hydrous oxides in the soils (Bowman and Cole, 1978a, b; McLaughlin et al., 1977) was extracted with $0.5 \mathrm{M} \mathrm{NaOH}$. The $\mathrm{NaOH}$ extract was acidified with concentrated $\mathrm{HCl}$ to separate highly stable $\mathrm{P}_{0}$, associated with humic acid $\left(\mathrm{HA}-\mathrm{P}_{\mathrm{o}}\right)$ from the moderately stable $\mathrm{P}_{\mathrm{o}}$ related to 
fulvic acid $\left(F A-P_{0}\right)$. The $P_{i}$ concentration in all extracts was determined colorimetrically by the ammonium-molybdateascorbic method according to Murphy and Riley (Murphy and Riley, 1962). Total $\mathrm{P}\left(\mathrm{P}_{\mathrm{t}}\right)$ concentration in the $\mathrm{NaHCO}_{3}$ and $\mathrm{HCl}$ extracts was determined by inductively coupled plasmaoptical emission spectrometry. The $\mathrm{P}_{t}$ in the humic and fulvic acid extracts was determined by persulfate oxidation. The $P_{0}$ was calculated as the difference between $\mathrm{P}_{t}$ and $\mathrm{P}_{\mathrm{i}}$. The soil total organic $P\left(T P_{0}\right)$ was calculated as sum of $P_{0}$ fractions: labile- $\mathrm{P}_{\mathrm{o}}+\mathrm{HCl}-\mathrm{P}_{\mathrm{o}}+\mathrm{FA}-\mathrm{P}_{\mathrm{o}}+\mathrm{HA}-\mathrm{P}_{\mathrm{o}}$.

\subsection{Statistical analysis}

The presented data are mean values of three independent field replicates. The effect of the different land-use systems on the (measured properties) different $\mathrm{P}$ fractions at the respective soil depths was evaluated by a two-way analysis of variance (ANOVA) at significant level of $5 \%(p \leq 0.05)$. When the effects were significant Holm-Sidak multiple comparison procedure was used to identify the source causing the effect. The Pearson correlation matrix was used to assess the strength of association among the different $P$ fractions at significant level of $1 \%(p \leq 0.01)$. All statistical analyses were carried out using Sigma Stat. version 3.0 (Jandel Scientific).

\section{Results and discussion}

\subsection{General soil properties}

Chemical properties of the different land-use systems are presented in Tab. 1. The arable sites had significantly lower TOC and TN content relative to the SP and SP-GL system at the $0-10 \mathrm{~cm}$ layer $(p<0.05)$. The TOC content of SP-AL was $\approx 19 \%$ lower than that found at SP site. Similar trend was observed for TN content. This perhaps could be attributed to the mixing of arable soil up to $20 \mathrm{~cm}$ depth through tillage practices, which enhance aeration and consequently, promotes degradation of organic matter (OM) (Angers et al., 1993). In addition, the higher TOC and TN contents in the topsoil under SP and SP-GL systems compared to arable soils can also be explained by the higher input of biomass from grass and trees on SP and SP-GL sites. Besides, the higher TN and TOC at the topsoils of the SP system may be attributed to high additions of root-derived $\mathrm{C}$, root exudates from dense rooting systems, and high input of OM from dung through cattle grazing.

Factors affecting $P$ stability, retention of chemical fractions and distributions in the soil profile may vary depending on the type of land-use. The TP content in SP system was higher compared to SP-GL, which is in agreement with the results of Michel et al. (2007), who demonstrate that in treeless pasture sites, the capacity of soil to store additional $P$ was lower compared to SP system. This is probably related to more complex root system in SP, where roots of trees and grass may absorb soil nutrients more efficiently than in grassland (Nair et al., 2007). However, there were no significant differences in TP and P stock among the studied sites and at the respective soil depths.

The amount of extractable $\mathrm{P}_{\mathrm{MB}}$ was affected by the type of cultivation system in the order: SP-GL $>\mathrm{SP}=\mathrm{SP}-\mathrm{AL}=\mathrm{AL}$ (Tab.1). The $\mathrm{P}_{\mathrm{MB}}$ as a major biological indicator of soil fertility was within the range reported in the literature (Brookes et al., 1984; He et al., 1997; Oberson et al., 1993). Significantly higher $\mathrm{P}_{\mathrm{MB}}$ content was found in the $0-10 \mathrm{~cm}$ layer under SP-GL $\left(31.35 \mathrm{mg} \mathrm{kg}^{-1}\right)$ representing $\approx 5 \%$ of TP and $\approx 16 \%$ of $\mathrm{TP}_{\mathrm{O}}$ and was nearly twofold compared to that of SP and SP-AL sites ( $\approx 15 \mathrm{mg} \mathrm{kg}^{-1}$ ) (Tab.1). This suggests that conversion to grassland relatively increased the soil $\mathrm{P}_{\mathrm{MB}}$, while conversion to agricultural monoculture reduced soil $\mathrm{P}_{\mathrm{MB}}$. Similar decline was observed for soil microbial C (Matos et al., 2011). The presented $P_{M B}$ results were well within the range of soil microbial biomass $P$ in grassland and arable soils reported by Brookes et al. (1984). The higher $\mathrm{P}_{\mathrm{MB}}$ content at SP-GL site in comparison with AL site could be attributed to

Table 1: Soil chemical properties at the $0-10$ and $10-20 \mathrm{~cm}$ depths across the different land-use systems. Different letters within a column indicate significant difference $(n=3, p<0.05$, Holm-Sidak).

\begin{tabular}{|c|c|c|c|c|c|c|c|c|c|c|}
\hline \multirow[t]{2}{*}{ Treatment } & $\mathrm{pH}^{\star}$ & TOC & $\mathrm{TN}$ & OM & $\mathbf{P}_{\mathrm{MB}}$ & TP & $\mathbf{C}: \mathbf{P}$ & P stock & $\mathrm{Fe}_{\mathrm{ox}}{ }^{*}$ & $\mathrm{Al}_{\mathrm{ox}}{ }^{*}$ \\
\hline & & \multicolumn{2}{|c|}{$/ \mathrm{g} \mathrm{kg}^{-1}$} & \multicolumn{3}{|c|}{$/ \mathrm{mg} \mathrm{P} \mathrm{kg}^{-1}$} & & / kg ha-1 & \multicolumn{2}{|c|}{$/ \mathrm{mg} \mathrm{kg}^{-1}$} \\
\hline \multicolumn{11}{|l|}{$0-10 \mathrm{~cm}$} \\
\hline SP & $5.07 c$ & $10.92 a$ & $0.88 a$ & $18.8 a$ & $15.10 \mathrm{~b}$ & $685 a$ & $16.05 a b$ & $926 a$ & $1492 a$ & $902 a$ \\
\hline AL & $5.33 b c$ & $5.63 c$ & $0.57 b$ & $9.7 c$ & $7.52 b$ & $661 a$ & $9.06 c$ & $1008 a$ & $1501 a$ & $1053 a$ \\
\hline SP-GL & $5.66 \mathrm{~b}$ & $11.18 a$ & $0.88 a$ & $19.3 a$ & $31.35 a$ & $571 a$ & $19.76 a$ & $823 a$ & $1364 a$ & $793 a$ \\
\hline SP-AL & $6.30 \mathrm{a}$ & $8.79 b$ & $0.70 \mathrm{~b}$ & $15.2 b$ & $14.53 b$ & $741 a$ & $11.82 \mathrm{bc}$ & $1068 a$ & $1850 a$ & $740 a$ \\
\hline \multicolumn{11}{|l|}{$10-20 \mathrm{~cm}$} \\
\hline SP & $4.99 b$ & $5.08 b$ & $0.46 b$ & $8.8 b$ & $13.24 a$ & $728 a$ & $7.06 \mathrm{~b}$ & $1102 a$ & $1534 a$ & $1092 a$ \\
\hline$A L$ & $5.55 b$ & $5.67 b$ & $0.51 b$ & $9.8 b$ & $13.47 a$ & $672 a$ & $8.49 a b$ & $1087 a$ & $1619 a$ & $1142 a$ \\
\hline SP-GL & $5.43 b$ & $4.93 b$ & $0.45 b$ & $8.5 b$ & $21.59 a$ & $667 a$ & $7.48 b$ & $1167 a$ & $1642 a$ & $981 a b$ \\
\hline SP-AL & $6.33 a$ & $7.69 a$ & $0.62 a$ & $13.3 a$ & $20.27 a$ & $670 a$ & $11.52 \mathrm{a}$ & $1162 a$ & $1514 a$ & $643 b$ \\
\hline
\end{tabular}

* After Matos et al. (2011); TOC—-total organic C, TN—total N, OM-organic matter, $\mathrm{P}_{\mathrm{MB}}$-soil microbial biomass $\mathrm{P}, \mathrm{Al}_{\mathrm{ox}}$-oxalate-soluble $\mathrm{Al}$, $\mathrm{Fe}_{\mathrm{ox}}$-oxalate-soluble Fe. 
the influence of tillage practices on microbial activity (Alvarez et al., 1995). At $A L$ site the $P_{M B}$ comprised $\approx 4 \%$ of $T P_{0}$, while at SP-GL it was $\approx 16 \%$. However, at SP-AL site the $\mathrm{P}_{M B}$ was about $12 \%$ of $\mathrm{TP}_{\mathrm{O}}$. This observation may be due to the longer period associated with microbial biomass declining to low level often found in arable soils (Brookes et al., 1984). As noted by Hedley et al. (1982), microorganisms growing in a medium with high $\mathrm{P}$ content usually assimilate more $\mathrm{P}$ than in a medium with low $\mathrm{P}$ content.

\subsection{Sequential organic-P fraction}

The $P_{0}$ fractions react differently in different land-use systems. The labile- $P_{i}$ extracted by sodium bicarbonate represents a short-term plant-available $\mathrm{P}_{\mathrm{i}}$ pool (Bowman and Cole, 1978a), and was depleted under agriculturally cultivated soils compared to SP site; values were $\approx 51$ and $30 \mathrm{mg} \mathrm{kg}^{-1}$ for SP and arable soils, respectively (Tab. 2). Similar trend was observed for labile- $P_{0}$ concentration, which has been suggested to be an active fraction of $P_{0}$, and probably represents compounds that are readily exchangeable from the soil (Bowman and Cole, 1978a). The content of labile- $\mathrm{P}_{\mathrm{o}}$ at both soil layers was higher at SP site than at SP-AL and was $\approx 12 \%$ and $6 \%$ of $\mathrm{TP}_{0}$, respectively (Fig.1). The fact that, the labile- $\mathrm{P}_{\mathrm{i}}$ at $\mathrm{SP}$, SP-GL, and SP-AL sites was more pronounced than the labile- $P_{0}$ may indicate a higher $P_{0}$ mineralization in these soils. Moreover, the significantly $(p<0.05)$ higher labile- $\mathrm{P}_{\mathrm{o}}$ at SP and SP-GL sites (the same as $\mathrm{P}_{\mathrm{MB}}$ ) than at arable sites at the $10-20 \mathrm{~cm}$ layer may presumably be due to the absence of soil disturbance by cultivation, thus leading to the build up of microbial biomass that can immobilize $P$ from the available P forms (Brookes et al., 1984; Song et al., 2007). Additionally, higher OM returns in the form of litter and excreta into SP soil and the higher root biomass in the top $20 \mathrm{~cm}$ layer at SP and SP-GL sites promotes microbial growth and activity and consequently mineralization of $\mathrm{P}$ (Tiessen et al., 1984). On the other hand, lime application at SP-AL site could reduce the content of the labile- $P_{0}$ fractions and enhance microbial activity, which may results in more rapid mineralization of soil OM and $\mathrm{P}_{\mathrm{o}}$ (Alt et al., 2011; McKenzie et al., 1992). Despite the fact that values shows relative decrease in labile- $P_{0}$ content at SP-AL site at the $0-10 \mathrm{~cm}$ soil layer, no significant difference was found among the investigated sites owing to the high spatial variability in the data set.

It is well known that soils with a high proportion of labile $\mathrm{P}$ pools indicate greater potential availability (Castillo and Wright, 2008). In our study the labile $P$, an index of $P$ availability (Bowman and Cole, 1978a; Olsen et al., 1954), indicates siginificantly lower $\mathrm{P}$ availability in the cultivated arable soils with value $\approx 5 \%$ of TP (Fig. 2 ) than in grassland soil (10\% of TP). This is in agrement with results obtained by Tiessen et al. (1983), Troitino et al. (2008), and Oberson et al. (2001). They observed that labile $P$ was greatly reduced during cultivation, indicating a significant reduction in $\mathrm{P}$ available. Probably, this reduction is related to soil OM content, which was higher at SP and SP-GL sites. Moreover, higher concentrations of $\mathrm{P}$ available at SP and SP-GL sites were probably associated with the interaction between greater biological cycling due to a higher litter addition at these sites compared to arable lands with low OM input as a result of straw harvesting. Consequently, the content of $P$ available under SP-GL system was similar to that of SP system but lower at the SP-AL site. On the other hand, the main influence on $P$ availability is soils $\mathrm{pH}$ (Haynes, 1982), which was around 5.3 at SP, AL, and SP-GL sites and 6.3 at the limed SP-AL site. The $\mathrm{P}$ available was approx. twice lower at SP-AL site compared to the other sites (Fig. 2), and it is probably related to the higher $\mathrm{pH}$ values at this site. Studies carried out on grassland soils in the UK by McDowell et al. (2002), showed that in soils with $\mathrm{pH}$ lower than 5.8 , the labile $\mathrm{P}$ concentration was twice higher compared to soils with $\mathrm{pH}$ above this level. This is probably due to hydrolysis of $\mathrm{Al}$ - and $\mathrm{Fe}-\mathrm{P}$ in soils with

Table 2: Phosphorus $(\mathrm{P})$ concentration in the various extracts at the $0-10 \mathrm{~cm}$ and $10-20 \mathrm{~cm}$ soil depths across the different land-use systems. Mean values $(n=3) \pm$ standard error.

\begin{tabular}{|c|c|c|c|c|c|c|c|c|c|}
\hline \multirow[t]{3}{*}{ Treatment } & \multicolumn{8}{|c|}{ Soil $P$ fraction } & \multirow{2}{*}{$\frac{\text { Sum }}{\mathrm{TP}_{\mathrm{o}} \mathrm{b}}$} \\
\hline & labile- $\mathrm{P}_{\mathrm{i}}{ }^{\mathrm{a}}$ & labile- $P_{0}$ & $\mathrm{HCl}-\mathrm{P}_{\mathrm{i}}$ & $\mathrm{HCl}-\mathrm{P}_{\mathrm{o}}$ & $\mathrm{NaOH}-\mathrm{P}_{\mathrm{i}}$ & $\mathrm{NaOH}-\mathrm{P}_{\mathrm{o}}$ & $F A-P_{0}$ & $\mathrm{HA}-\mathrm{P}_{\mathrm{o}}$ & \\
\hline & \multicolumn{9}{|c|}{ / mg P kg-1 } \\
\hline \multicolumn{10}{|l|}{$0-10 \mathrm{~cm}$} \\
\hline SP & $50.83 a$ & $16.70 \mathrm{a}$ & $269.56 a$ & $6.56 \mathrm{~b}$ & $25.35 a b$ & $85.82 a$ & $41.89 a$ & $69.29 a$ & $134.44 a$ \\
\hline$A L$ & $29.89 \mathrm{~b}$ & $15.59 a$ & $261.25 a$ & $25.46 a$ & $36.32 a$ & $93.97 a$ & $42.75 a$ & $87.54 a$ & $171.34 a$ \\
\hline SP-GL & $44.55 a b$ & $12.40 \mathrm{a}$ & $211.76 a$ & $23.68 \mathrm{a}$ & $39.06 a$ & $126.13 a$ & $51.83 a$ & $113.36 a$ & $201.28 \mathrm{a}$ \\
\hline SP-AL & $28.51 b$ & $7.36 a$ & $234.84 a$ & $3.61 b$ & $14.24 b$ & $97.42 \mathrm{a}$ & $23.80 a$ & $87.85 a$ & $122.63 a$ \\
\hline \multicolumn{10}{|l|}{$10-20 \mathrm{~cm}$} \\
\hline SP & $56.90 a$ & $17.72 a$ & $267.60 \mathrm{a}$ & $11.97 b$ & $50.50 a$ & $104.33 a$ & $55.91 \mathrm{a}$ & $98.93 a$ & $184.51 \mathrm{a}$ \\
\hline$A L$ & $34.89 \mathrm{~b}$ & $8.34 b$ & $218.50 a$ & $19.26 a$ & $35.84 b$ & $107.47 a$ & $51.91 a$ & $93.24 a$ & $172.75 a$ \\
\hline SP-GL & $40.44 a b$ & $16.26 a$ & $212.40 a$ & 13.50ab & $36.48 b$ & $118.94 a$ & $59.55 a$ & $95.87 a$ & $185.18 \mathrm{a}$ \\
\hline SP-AL & $31.98 \mathrm{~b}$ & $5.49 \mathrm{~b}$ & $236.73 a$ & $1.50 \mathrm{c}$ & $15.51 \mathrm{c}$ & $81.95 a$ & $32.62 b$ & $64.84 a$ & $103.96 b$ \\
\hline
\end{tabular}




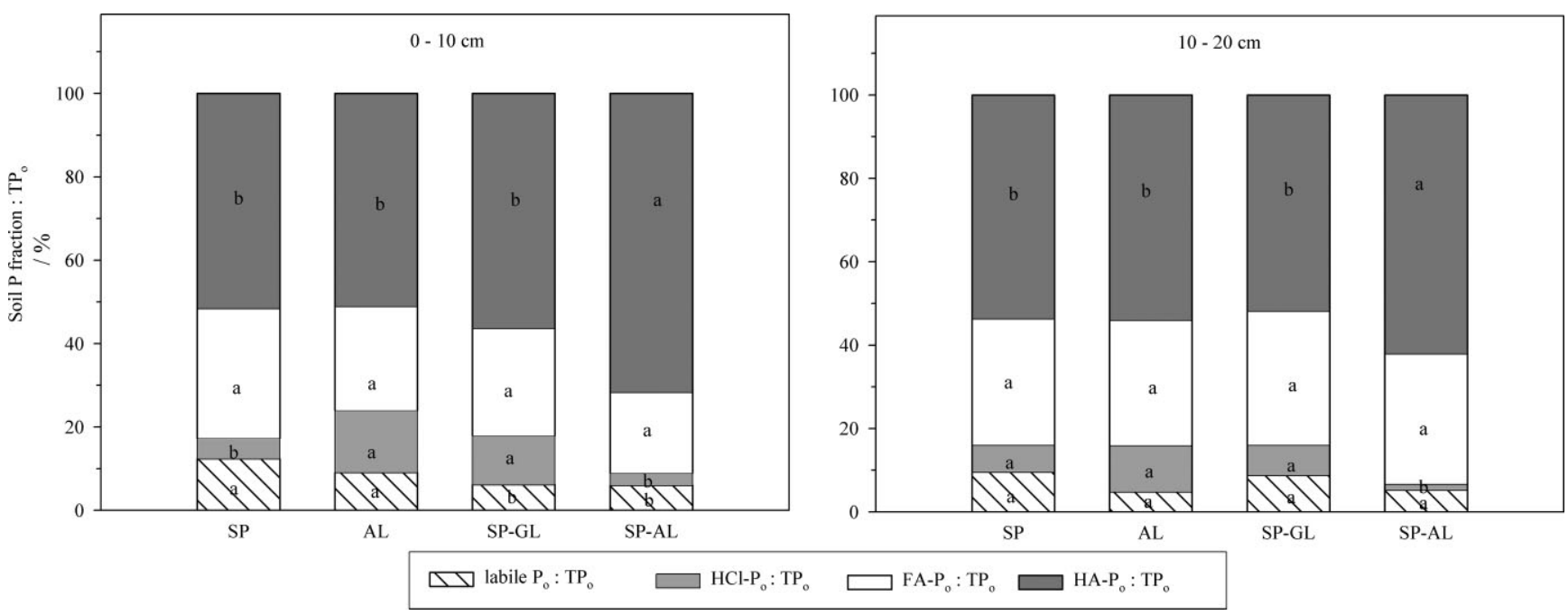

Figure 1: The proportion of $P$ fractions to soil total organic $P\left(T_{0}\right)$ in mineral soil at $0-10 \mathrm{~cm}$ and $10-20 \mathrm{~cm}$ depth, under silvopasture system $(\mathrm{SP})$, arable land $(\mathrm{AL})$, silvopasture converted to grassland (SP-GL), and silvopasture converted to arable land (SP-AL). Different letters within the same depths indicates significant difference among the sites $(p<0.05$, Holm-Sidak).

$\mathrm{pH}<5.8$ and $\mathrm{Ca}-\mathrm{P}$ in soils with $\mathrm{pH}>5.8$. Our results, which revealed a general increase in soluble $\mathrm{P}$ with increased $\mathrm{pH}$ to 6.3 at the limed SP-AL site concur with the findings of McDowell et al. (2002). Moreover, positive correlation was observed between the labile- $\mathrm{P}_{\mathrm{o}}$ and $\mathrm{Al}_{\mathrm{ox}}(p=0.05)$ (Tab. 3). Thus, in general, land-management practice could have an impact on labile $\mathrm{P}$ even though these changes could also be influenced by the soil $\mathrm{pH}$. However, the detected amounts of available $\mathrm{P}$ were in the range of $\mathrm{P}$ content optimal for plant growth for soils in Germany (KTBL, 2005).

The $\mathrm{HCl}-\mathrm{P}_{\mathrm{i}}$ fraction was dominated by all inorganic soil $\mathrm{P}$ pools, and constitutes up to $39 \%$ of TP at the SP site. The high content of $\mathrm{HCl}-\mathrm{P}_{\mathrm{i}}$ fraction at SP-AL site may be attributed to secondary $\mathrm{Ca}$ phosphate minerals formed after lime application. It has been observed that the $\mathrm{HCl}-\mathrm{P}$ pool increases with continuous fertilization and cropping (Verma et al., 2005). According to $Y u$ et al. (2006), the HCl-P fractions contributed mostly to the TP in neutral and alkaline soils. Nevertheless, the other sites, which did not receive any fertilizer and lime application also showed very high $\mathrm{HCl}-\mathrm{P}_{\mathrm{i}}$ concentration. However, there were no significant differences among sites. It is assumed that these high $\mathrm{HCl}-\mathrm{P}_{\mathrm{i}}$ values are related to the release of $\mathrm{P}$ from metal oxidation, since $\mathrm{HCl}-\mathrm{P}_{\mathrm{i}}$ fraction reflect to $\mathrm{P}$ bound to Ca minerals.

On the other hand, the results of $\mathrm{HCl}-\mathrm{P}_{0}$ pool showed the impact of change in land-use on this $P$ fraction (Tab.2). In soil at the short-term SP-AL site, the content of $\mathrm{HCl}-\mathrm{P}_{\mathrm{o}}$ pool was significantly lower than at the long-term $\mathrm{AL}$ site at both soil layers $(45 \%$ and $92 \%$ at the $0-10$ and $10-20 \mathrm{~cm}$ layers, respectively). The difference between the arable lands could be as a result of differences in soil $\mathrm{pH}$ and/or in crop types ( $A L$ site vegetated by rye and SP-AL by rape), or crop-residue management systems. Otherwise, this could indicate that the mineralization of $\mathrm{P}_{\mathrm{o}}$ fractions and transformation into $\mathrm{HCl}-\mathrm{P}_{\mathrm{o}}$ might depend on land-use and land-management system.
The $\mathrm{NaOH}-\mathrm{P}_{\mathrm{i}}$ fraction is thought to represent $\mathrm{Al}$ - and Febound inorganic $\mathrm{P}$, constitute $<7 \%$ of TP across the investigated site, and was significantly higher at SP-GL compared to SP-AL site. This may likely be a result of the lime application at the SP-AL site. It has been documented that application of lime decreased the $\mathrm{NaOH}-\mathrm{P}_{i}$ pool, by the precipitation of soluble $\mathrm{Fe}$ and $\mathrm{Al}$ ions, since the $\mathrm{NaOH}-\mathrm{P}_{\mathrm{i}}$ pool is held strongly by chemisorption to $\mathrm{Fe}$ and $\mathrm{Al}$ soil components (McKenzie et al., 1992; Sharma et al., 1995). Furthermore, no significant positive correlation $(p<0.01)$ was found between $\mathrm{Al}$ oxide and $\mathrm{NaOH}-\mathrm{P}_{\mathrm{i}}$ fraction reflecting $\mathrm{P}$ bound to $\mathrm{Al}$ and $\mathrm{Fe}$ oxides. However, it has been suggested that the $\mathrm{NaOH}-\mathrm{P}_{\mathrm{i}}$ fraction may maintain the levels of $\mathrm{P}$ availability through P desorption (McKenzie et al., 1992).

The $\mathrm{NaOH}-\mathrm{P}_{\mathrm{o}}$ forms were the most abundant $\mathrm{P}_{\mathrm{o}}$ fractions, and therefore can be considered as an important $\mathrm{P}$ source. At the $0-10 \mathrm{~cm}$ soil layer, the significantly highest $\mathrm{NaOH}-\mathrm{P}_{\mathrm{o}}$ fraction was observed at SP-GL site. Nevertheless, there was no difference in $\mathrm{NaOH}-\mathrm{P}_{0}$ between the arable sites. Probably the $\mathrm{NaOH}-\mathrm{P}_{\mathrm{o}}$ fraction was not affected by the land conversion. The relative distribution of this $\mathrm{P}$ fraction at SP-GL site is comparable with other studies, for example, grassland soil in Ireland (Herlihy and McGrath, 2007), Germany (Khan and Joergensen, 2012), and New Zealand (Chen et al., 2003). This suggests that soil $P$ extracted by $\mathrm{NaOH}$ (next to $\mathrm{P}$ extracted by $\mathrm{NaHCO}_{3}$ ) can be considered as the most biologically available $\mathrm{P}$ in soil (Chen et al., 2000; Tiessen and Moir, 1993) and may represent the largest fraction with significant contributions to $\mathrm{P}$ available for plants. Lilienfein et al. (2000) found that land-use influence was stronger on $\mathrm{P}$ fractions extracted by $\mathrm{NaOH}$ and $\mathrm{NaHCO}_{3}$ than on the other forms of $\mathrm{P}$. Moreover, the $\mathrm{NaOH}-\mathrm{P}_{\mathrm{o}}$ pool acts as a $P$ sink and becomes $P$ source when the labile $P$ is depleted, which may help to reduce the use of $P$ fertilizers.

The FA and HA fractions generally represent a stable fraction of $P$ associated with OM (Castillo and Wright, 2008). Signifi- 
Table 3: Pearson correlation matrix. Values represent correlation coefficient $(r)$.

\begin{tabular}{|c|c|c|c|c|c|c|c|c|c|c|c|c|c|}
\hline Variable for $0-10 \mathrm{~cm}$ & 1 & 2 & 3 & 4 & 5 & 6 & 7 & 8 & 9 & 10 & 11 & 12 & 13 \\
\hline 1 labile- $P_{i}$ & 1.00 & & & & & & & & & & & & \\
\hline 2 labile- $P_{0}$ & 0.55 & 1.00 & & & & & & & & & & & \\
\hline $3 \mathrm{NaOH}-\mathrm{P}_{\mathrm{i}}$ & 0.27 & 0.58 & 1.00 & & & & & & & & & & \\
\hline $4 \mathrm{NaOH}-\mathrm{P}_{\mathrm{o}}$ & 0.11 & -0.31 & 0.52 & 1.00 & & & & & & & & & \\
\hline $5 \mathrm{HCl}-\mathrm{P}_{\mathrm{i}}$ & 0.07 & 0.64 & -0.17 & -0.93 & 1.00 & & & & & & & & \\
\hline $6 \mathrm{HCl}-\mathrm{P}_{\mathrm{o}}$ & -0.07 & 0.39 & ${ }^{\star *} 0.94$ & 0.53 & -0.24 & 1.00 & & & & & & & \\
\hline $7 \quad F A-P_{i}$ & ${ }^{\star \star} 0.70^{\mathrm{b}}$ & ${ }^{\star} 0.98$ & *0.55 & -0.26 & 0.57 & 0.30 & 1.00 & & & & & & \\
\hline 8 FA-P。 & ${ }^{*} 0.60$ & ${ }^{\star *} 0.67$ & **0.93 & 0.50 & -0.15 & 0.75 & ${ }^{\star *} 0.70$ & 1.00 & & & & & \\
\hline 9 TOCa & **0.80 & -0.05 & -0.07 & 0.37 & -0.38 & -0.34 & 0.13 & 0.26 & 1.00 & & & & \\
\hline 10 TP & -0.45 & -0.35 & -0.90 & -0.78 & 0.50 & -0.78 & -0.39 & -0.93 & -0.31 & 1.00 & & & \\
\hline $11 \mathrm{TP}_{\mathrm{o}}$ & 0.18 & 0.27 & ${ }^{\star \star} 0.94$ & ${ }^{* \star} 0.78$ & -0.51 & ${ }^{* *} 0.92$ & 0.26 & ${ }^{* *} 0.85$ & 0.04 & -0.95 & 1.00 & & \\
\hline $12 \mathrm{Fe}_{\mathrm{ox}}$ & -0.64 & -0.73 & -0.91 & -0.41 & 0.06 & -0.71 & -0.77 & -0.99 & -0.26 & ${ }^{\star *} 0.89$ & -0.80 & 1.00 & \\
\hline $13 \mathrm{Al}_{\mathrm{ox}}$ & -0.08 & ${ }^{* *} 0.79$ & ${ }^{*} 0.51$ & -0.44 & 0.70 & 0.52 & ${ }^{*} 0.66$ & 0.36 & -0.65 & -0.09 & 0.20 & -0.41 & 1.00 \\
\hline
\end{tabular}

\begin{tabular}{|c|c|c|c|c|c|c|c|c|c|c|c|c|c|}
\hline Variable for $10-20 \mathrm{~cm}$ & 1 & 2 & 3 & 4 & 5 & 6 & 7 & 8 & 9 & 10 & 11 & 12 & 13 \\
\hline 1 labile- $P_{i}$ & 1.00 & & & & & & & & & & & & \\
\hline 2 labile- $P_{0}$ & ${ }^{\star \star} 0.85$ & 1.00 & & & & & & & & & & & \\
\hline $3 \mathrm{NaOH}-\mathrm{P}_{\mathrm{i}}$ & ${ }^{\star \star} 0.87$ & ${ }^{*} 0.85$ & 1.00 & & & & & & & & & & \\
\hline $4 \mathrm{NaOH}-\mathrm{P}_{\mathrm{o}}$ & 0.34 & 0.71 & ${ }^{\star} 0.69$ & 1.00 & & & & & & & & & \\
\hline $5 \mathrm{HCl}-\mathrm{P}_{\mathrm{i}}$ & ${ }^{\star} 0.74$ & 0.31 & 0.39 & -0.37 & 1.00 & & & & & & & & \\
\hline $6 \mathrm{HCl}-\mathrm{P}_{\mathrm{o}}$ & 0.20 & 0.36 & ${ }^{*} 0.66$ & 0.81 & -0.32 & 1.00 & & & & & & & \\
\hline 7 FA- $P_{i}$ & ${ }^{\star \star} 0.86$ & ${ }^{*} 0.92$ & 0.99 & ${ }^{\star \star} 0.76$ & ${ }^{*} 0.32$ & 0.64 & 1.00 & & & & & & \\
\hline 8 FA- $P_{0}$ & 0.58 & ${ }^{*} 0.84$ & ${ }^{\star *} 0.86$ & ${ }^{\star *} 0.96$ & -0.10 & ${ }^{*} 0.79$ & ${ }^{* *} 0.91$ & 1.00 & & & & & \\
\hline 9 TOC & -0.64 & ** -0.86 & -0.90 & -0.94 & 0.02 & ** -0.78 & -0.94 & $* *-1.00$ & 1.00 & & & & \\
\hline 10 TP & 0.93 & 0.61 & 0.73 & 0.02 & 0.92 & 0.05 & 0.67 & 0.30 & -0.38 & 1.00 & & & \\
\hline $11 \mathrm{TP}_{\mathrm{o}}$ & 0.62 & ${ }^{\star \star} 0.82$ & ${ }^{* *} 0.91$ & ${ }^{* *} 0.92$ & -0.02 & ${ }^{* *} 0.83$ & ${ }^{\star *} 0.94$ & ${ }^{* *} 0.99$ & ${ }^{* *}-0.99$ & 0.38 & 1.00 & & \\
\hline $12 \mathrm{Fe}_{\mathrm{ox}}$ & -0.20 & 0.25 & 0.25 & 0.85 & -0.79 & 0.76 & 0.33 & 0.68 & -0.63 & $* *-0.48$ & 0.62 & 1.00 & \\
\hline $13 \mathrm{Al}_{\mathrm{ox}}$ & 0.51 & 0.56 & ${ }^{* *} 0.87$ & ${ }^{\star *} 0.77$ & 0.02 & ${ }^{* *} 0.94$ & ${ }^{\star *} 0.83$ & 0.85 & -0.86 & ${ }^{*} 0.39$ & ${ }^{\star *} 0.90$ & ${ }^{* *} 0.55$ & 1.00 \\
\hline
\end{tabular}

a TOC—total organic carbon; $\mathrm{Al}_{\mathrm{ox}}$-oxalate-soluble $\mathrm{Al}$; $\mathrm{Fe}_{\mathrm{ox}}$-oxalate-soluble Fe.

$\mathrm{b} *$. ${ }^{* *}$ significant at $p<0.05$ and $p<0.01$, respectively.

cantly higher $\mathrm{HA}-\mathrm{P}_{\mathrm{o}}\left(72 \%\right.$ of $\left.\mathrm{TP}_{\mathrm{o}}\right)$ fraction was found in soils at SP-AL site (Fig.1). The significant difference between short-term arable site SP-AL and long-term AL site could be explained by the incorporation of dung through prior cattle grazing at SP-AL site, which could stimulate OM decomposition and $P$ mineralization. The values of $F A-P_{0}$ at $A L$ site were comparable with the values of arable soils presented by Sharpley (1985).

The $\mathrm{TP}_{0}$ as a percentage of TP ranged between $16 \%$ and $35 \%$ (Fig. 3). The $\mathrm{TP}_{\mathrm{o}}$ followed similar trend as the $\mathrm{P}_{\mathrm{MB}}$ with the highest value at the SP-GL site, which was $17 \%$ higher than that of the adjacent cultivated AL site (Tab. 2). This is in agreement with Hedley et al. (1982) and Magid (1993), and may be attributed to the absence of tillage practices at SP-GL site resulting in higher accumulation of $O M$, this may alter the dynamics of $\mathrm{OM}$ and consequently affect the $\mathrm{TP}_{\mathrm{o}}$ content at SP-GL compared to AL site (Guggenberger et al., 1996).
Besides, higher OM accumulation under SP-GL may be due to input of fine roots of grasses (Brady and Weil, 2002) and greater root turnover (Chen et al., 2000). Condron et al. (2005) noted that the content of $\mathrm{TP}_{\mathrm{o}}$ in soils may vary between $20 \%$ and $90 \%$ of TP but only a small fraction of this is present in labile form. Additionally, the highest proportion of $\mathrm{TP}_{\mathrm{o}}$ at the SP-GL site might be related to the higher OM content and its fractions, since there was significant correlation between the $\mathrm{TP}_{\mathrm{o}}$ and $\mathrm{OM}$ with the labile- $\mathrm{P}_{\mathrm{o}}$ content in the $10-20 \mathrm{~cm}$ soil layer $(p \leq 0.01)$. A significant correlation between the $\mathrm{TP}_{\mathrm{o}}$ and the labile forms of $\mathrm{P}$ has been observed by Kizilkaya et al. (2007).

Strong positive correlations between $\mathrm{TP}_{\mathrm{O}}$ and different $\mathrm{P}$ pools were found for $\mathrm{NaOH}-\mathrm{P}_{\mathrm{i}}$ and $\mathrm{NaOH}-\mathrm{P}_{0}, \mathrm{HCl}-\mathrm{P}_{0}$ and FA- $\mathrm{P}_{0}$ in both soil layers $(p \leq 0.01)$ as well as for labile- $\mathrm{P}_{\mathrm{o}}$ at the $10-20 \mathrm{~cm}$ soil layer $(p \leq 0.01)$ (Tab. 3). This concurs with findings of Guggenberger et al. (1996), that the labile- $P_{0}$ is a 


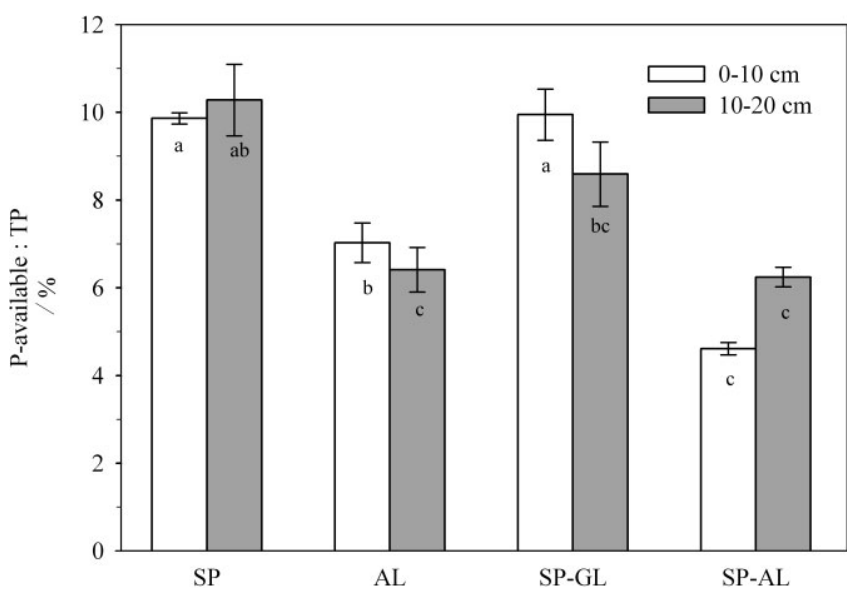

Figure 2: The proportion of plant available $P$ to soil total $P$ (TP) in mineral soil at $0-10 \mathrm{~cm}$ and $10-20 \mathrm{~cm}$ depth. Error bars represent standard deviations of the mean values. Different letters within the same depths indicates significant difference among the sites $(p<0.05$, Holm-Sidak).

reflection of $\mathrm{TP}_{0}$, and its availability depends on $\mathrm{TP}_{0}$ and microbial activity. The Pearson correlation coefficients were similar to the correlation that has been observed in other studies (Negassa and Leinweber, 2009). This indicates that the concentration of different $P$ pools may depend as well on some other variables including, soil properties, plant $\mathrm{P}$ uptake, OM decomposition, or land-management practices.

\section{Conclusions}

The main focus of this study was to discuss the influence of $\mathrm{TP}_{\mathrm{o}}$ distribution in soils after land conversion. Therefore the discussion is mainly focused on the organic-P fractions. On the basis of the presented data, the type of land use seems to be an important factor controlling $P$ forms and $P$ availability in soil. However, the TP and $\mathrm{P}$ stock were not affected by the conversion of SP land to arable and grassland, although lower $\mathrm{TP}_{\mathrm{o}}$ was observed for land converted to arable use. Nevertheless, only 4 y after converting temperate SP system to arable and grassland use altered differently the various organic and inorganic $P$ pools. The most apparent impact was on labile- $\mathrm{P}_{\mathrm{i}}$, labile- $\mathrm{P}_{\mathrm{o}}$, and $\mathrm{NaOH}-\mathrm{P}_{\mathrm{i}}$ forms, where significantly higher values were observed for SP and SP-GL sites compared to short-term cultivated arable land (SP-AL). Moreover, changes in $\mathrm{P}$ available were mainly at the arable SP-AL site. This indicates that in SP system the $P$ available is preserved at the expense of organic $P$ cycling and can therefore serve as an important land-use practice to increase soil $P$ availability. The presented variations in the content of various $\mathrm{P}$ pools among the different land-use forms may depend not only on land transformations but also on other factors including dissimilarity in crop-residue management, crop types, and different management practices. Even so, detailed long-term studies are needed to gain more insight into the effect of land transformation on $\mathrm{P}$ cycling in order to develop sustainable farming practices.

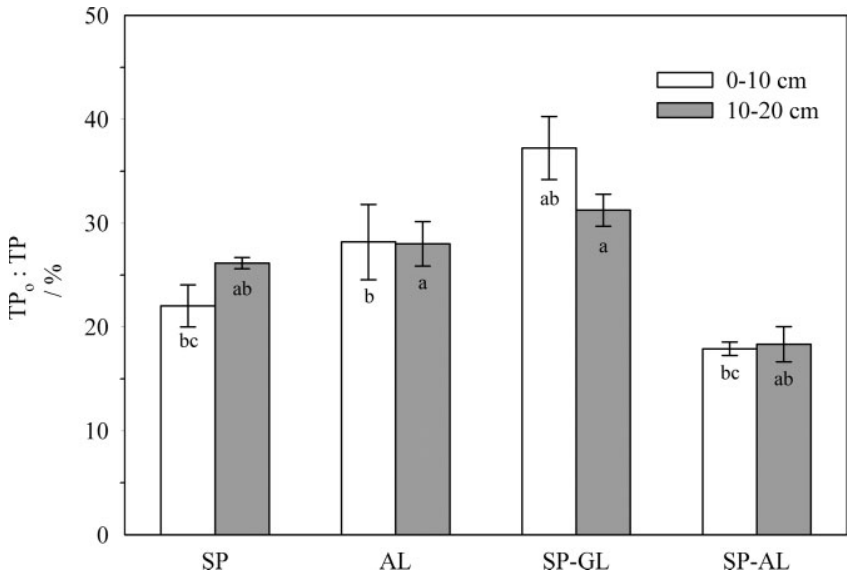

Figure 3: The proportion of total organic $P\left(T_{0}\right)$ to soil total $P(T P)$ for soil under silvopasture system (SP), arable land (AL), silvopasture converted to grassland (SP-GL), and silvopasture converted to arable land (SP-AL) at $0-10 \mathrm{~cm}$ and $10-20 \mathrm{~cm}$ depth. Error bars represent standard deviations of the means values. Different letters within the same depths indicates significant difference among the sites $(p<0.05$, Holm-Sidak).

\section{Acknowledgments}

This research was partly supported by the International Graduate School (IGS) of Brandenburg University of Technology, Cottbus, Germany. We would like to thank G. Ehode for her assistance during soil sampling and soil preparations, and anonymous reviewers for their valuable suggestions.

\section{References}

Alt, F., Oelmann, Y., Herold, N., Schrumpf, M., Wilcke, W. (2011): Phosphorus partitioning in grassland and forest soils of Germany as related to land-use type, management intensity, and land userelated pH. J. Plant Nutr. Soil Sci. 174, 195-209.

Alvarez, R., Santanatoglia, O. J., Garcea, R. (1995): Effect of temperature on soil microbial biomass and its metabolic quotient in situ under different tillage systems. Biol. Fertil. Soils 19, 227-230.

Angers, D. A., Bossonnettee, N., Legere, A., Samson, N. (1993): Microbial and biochemical changes induced by rotation and tillage in soil under barley production. Can. J. Soil Sci. 7, 39-50.

Bowman, R. A., Cole, C. V. (1978a): An exploratory method for fractionation of organic phosphorus from grassland soils. Soil Sci. 125, 95-101.

Bowman, R. A., Cole, C. V. (1978b): Transformations of organic phosphorus substrates in soils as evaluated by $\mathrm{NaHCO}_{3}$ extraction. Soil Sci. 125, 49-54.

Brady, N. C., Weil, R. R. (2002): The Nature and Properties of Soil. Prentice Hall, New Jersey, p. 975

Brookes, P. C., Powlson, D. S., Jenkinson, D. S. (1982): Measurement of microbial biomass phosphorus in soil. Soil Biol. Biochem. 14, 319-329.

Brookes, P. C., Powlson, D. S., Jenkinson, D. S. (1984): Phosphorus in the soil microbial biomass. Soil Biol. Biochem. 16, 169-175.

Castillo, M. S., Wright, A. L. (2008): Soil phosphorus pools for Histosols under sugarcane and pasture in the Everglades, USA. Geoderma 145, 130-135. 
Chen, C., Condron, L., Davis, M., Sherlock, R. (2000): Effects of afforestation on phosphorus dynamics and biological properties in a New Zealand grassland soil. Plant Soil 220, 151-163.

Chen, C. R., Sinaj, S., Condron, L. M., Frossard, E., Sherlock, R. R., Davis, M. R. (2003): Characterization of phosphorus availability in selected New Zealand grassland soils. Nutr. Cycl. Agroecosys. 65, 89-100.

Condron, L. M., Turner, B. L., Cade-Menun, B. J. (2005): Chemistry and dynamics of soil organic phosphorus, in Sims, J. T., Sharpley, A. N. (eds.): Phosphorus: Agriculture and the Environment. ASA/ CSSA/SSSA, Madison, Wisconsin, USA, pp. 87-121.

Cross, A. F., Schlesinger, W. H. (1995): A literature review and evaluation of the Hedley fractionation: Applications to the biogeochemical cycle of soil phosphorus in natural ecosystems. Geoderma 64, 197-214.

Di, H. J., Condron, L. M., Frossard, E. (1996): Isotope techniques to study phosphorus cycling in agricultural and forest soils: a review. Biol. Fertil. Soils 24, 1-12.

Ellert, B. H., Gregorich, E. G. (1996): Storage of carbon, nitrogen and phosphorus in cultivated and adjacent forested soils of Ontario. Soil Sci. 161, 587-603.

Guggenberger, G., Christensen, B. T., Rubek, G., Zech, W. (1996): Land-use and fertilization effects on $P$ forms in two European soils: resin extraction and ${ }^{31}$ P-NMR analysis. Eur. J. Soil Sci. 47, 605614.

Haynes, R. J. (1982): Effects of liming on phosphate availability in acid soils. Plant Soil 68, 289-308.

He, Z. L., Wu, J., O'Donnell, A. G., Syers, J. K. (1997): Seasonal responses in microbial biomass carbon, phosphorus and sulphur in soils under pasture. Biol. Fertil. Soils 24, 421-428.

Hedley, M. J., Stewart, J. W. B., Chauhan, B. S. (1982): Changes in inorganic and organic soil phosphorus fractions induced by cultivation practices and by laboratory incubations. Soil Sci. Soc. Am. J. 46, 970-976.

Herlihy, M., McGrath, D. (2007): Phosphorus fractions and adsorption characteristics in grassland soils of varied soil phosphorus status. Nutr. Cycl. Agroecosys. 77, 15-27.

Islam, K. R., Weil, R. R. (1998): Microwave irradiation of soil for routine measurement of microbial biomass carbon. Biol. Fertil. Soils 27, 408-416.

Khan, K. S., Joergensen, R. G. (2012): Relationships between P fractions and the microbial biomass in soils under different land use management. Geoderma 173, 274-281.

Kizilkaya, R., Bayrakli, F., Surucu, A. (2007): Relationship between phosphatase activity and phosphorus fractions in agricultural soils. Int. J. Soil Sci. 2, 107-118.

KTBL (Kuratorium für Technik und Bauwesen in der Landwirtschaft) (2005): Faustzahlen für die Landwirtschaft. Landwirtschaftsverlag, 13, Darmstadt, p. 1095.

Lilienfein, J., Wilcke, W., Ayarza, M. A., Vilela, L., do Carmo Lima, S., Zech, W. (2000): Chemical fractionation of phosphorus, sulphur, and molybdenum in Brazilian savannah Oxisols under different land use. Geoderma 96, 31-46.

Magid, J. (1993): Vegetation effects on phosphorus fractions in setaside soils. Plant Soil 149, 111-119.

Martens, D. A., Reedy, T. E., Lewis, D. T. (2004): Soil organic carbon content and composition of 130-year crop, pasture and forest landuse managements. Glob. Change Biol. 10, 65-78.

Matos, E., Freese, D., Mendonca, E., Slazak, A., Hüttl, R. (2011): Carbon, nitrogen and organic $C$ fractions in topsoil affected by conversion from silvopastoral to different land use systems. Agrofor. Syst. 81, 203-211.
McDowell, R. W., Brookes, P. C., Mahieu, N., Poulton, P. R., Johnston, A. E., Sharpley, A. N. (2002): The effect of soil acidity on potentially mobile phosphorus in a grassland soil. J. Agric. Sci. 139, 27-36.

McKeague, J. A., Day, J. H. (1966): Dithionite- and oxalate-extractable $\mathrm{Fe}$ and $\mathrm{Al}$ as aids in differentiating various classes of soils. Can. J. Soil Sci. 46, 13-22.

McKenzie, R. H., Stewart, J. W. B., Dormaar, J. F., Schaalje, G. B. (1992): Long-term crop rotation and fertilizer effects on phosphorus transformations: II. In a Luvisolic soil. Can. J. Soil Sci. 72, 581-589.

McLaughlin, J. R., Ryden, J. C., Syers, J. K. (1977): Development and evaluation of a kinetic model to describe phosphate sorption by hydrous ferric oxide gel. Geoderma 18, 295-307.

Michel, G. A., Nair, V., Nair, P. (2007): Silvopasture for reducing phosphorus loss from subtropical sandy soils. Plant Soil 297, 267-276.

Murphy, J., Riley, J. P. (1962): A modified single solution method for the determination of phosphate in natural waters. Anal. Chim. Acta 27, 31-36.

Nair, V. D., Nair, P. K. R., Kalmbacher, R. S., Ezenwa, I. V. (2007): Reducing nutrient loss from farms through silvopastoral practices in coarse-textured soils of Florida, USA. Ecol. Eng. 29, 192-199.

Negassa, W., Leinweber, P. (2009): How does the Hedley sequential phosphorus fractionation reflect impacts of land use and management on soil phosphorus: A review. J. Plant Nutr. Soil Sci. 172, 305-325.

Oberson, A., Fardeau, J. C., Besson, J. M., Sticher, H. (1993): Soil phosphorus dynamics in cropping systems managed according to conventional and biological agricultural methods. Biol. Fertil. Soils 16, 111-117.

Oberson, A., Friesen, D. K., Rao, I. M., Bühler, S., Frossard, E. (2001): Phosphorus transformations in an Oxisol under contrasting land-use systems: The role of the soil microbial biomass. Plant Soil 237, 197-210.

Olsen, S. R., Cole, C. V., Watanabe, F. S., Dean, L. A. (1954): Estimation of available phosphorus in soils by extraction with sodium bicarbonate. United States Department of Agriculture, Washington, p. 939

Sanyal, S. K., De Datta, S. K. (1991): Chemistry of Phosphorus Transformation in Soil, in Stewart, B. A. (ed.): Advances in Soil Science. Springer-Verlag, New York, pp. 2-94.

Schwertmann, U. (1964): Differenzierung der Eisenoxide des Bodens durch Extraktion mit Ammoniumoxalat-Lösung. Z. Pflanzenernähr. Bodenkd. 105, 194-202.

Sharma, S., Dhyani, B., Minhas, R. (1995): Inorganic phosphorus fractions in an Alfisol under long-term fertilizer experiment. $J$. Indian Soc. Soil Sci. 43, 466-468.

Sharpley, A. N. (1985): Phosphorus cycling in unfertilized and fertilized agricultural soils. Soil Sci. Soc. Am. J. 49, 905-911.

Sharpley, A. N., Smith, S. J. (1985): Fractionation of inorganic and organic phosphorus in virgin and cultivated soils. Soil Sci. Soc. Am. J. 49, 127-130.

Song, C., Han, $X$., Tang, C. (2007): Changes in phosphorus fractions, sorption and release in Udic Mollisols under different ecosystems. Biol. Fertil. Soils 44, 37-47.

Staley, T., Gonzalez, J., Neel, J. S. (2008): Conversion of deciduous forest to silvopasture produces soil properties indicative of rapid transition to improved pasture. Agrofor. Syst. 74, 267-277.

Tiessen, H., Moir, J. O. (1993): Characterization of Available P by Sequential Extraction, in Carter, M. R. (ed.): Soil Sampling and Methods of Analysis. Can. Society of Soil Sci., Boca Raton, pp. 75-86. 
Tiessen, H., Stewart, J. W. B., Bettany, J. R. (1982): Cultivation effects on the amounts and concentration of carbon, nitrogen, and phosphorus in grassland soils. Agron. J. 74, 831-835.

Tiessen, H., Stewart, J. W. B., Moir, J. O. (1983): Changes in organic and inorganic phosphorus composition of two grassland soils and their particle size fractions during 60-90 years of cultivation. Eur. J. Soil Sci. 34, 815-823.

Tiessen, H., Stewart, J. W. B., Cole, C. V. (1984): Pathways of phosphorus transformations in soils of differing pedogenesis. Soil Sci. Soc. Am. J. 48, 853-858.

Troitino, F., Gil-Sotres, F., Leiros, M. C., Trasar-Cepeda, C., Seoane, $S$. (2008): Effect of land use on some soil properties related to the risk of loss of soil phosphorus. Land Degrad. Dev. 19, 21-35.
Turrión, M. B., Gallardo, J. F., Haumaier, L., González, M. I., Zech, W. (2001): 31 P-NMR characterization of phosphorus fractions in natural and fertilized forest soils. Ann. For. Sci. 58, 89-98.

Verma, S., Subehia, S. K., Sharma, S. P. (2005): Phosphorus fractions in an acid soil continuously fertilized with mineral and organic fertilizers. Biol. Fertil. Soils 41, 295-300.

Yu, S., He, Z. L., Stoffella, P. J., Calvert, D. V., Yang, X. E., Banks, D. J., Baligar, V. C. (2006): Surface runoff phosphorus (P) loss in relation to phosphatase activity and soil $\mathrm{P}$ fractions in Florida sany soils under citrus production. Soil Biol. Biochem. 38, 619-628. 